\title{
The Effect of Organizational Commitment on Turnover Intentions with Work Stress as Intervening Variable At PT. Citra Perdana Kendedes Malang
}

\author{
Ryke Ayuningtyas* and Vivin Maharani
}

\author{
Department of Management, Faculty of Economics, \\ State Islamic University of Maulana Malik Ibrahim \\ Malang, Indonesia
}

\author{
E-mail: rykeeayuningtyas@gmail.com; vivien.maharani@yahoo.com
}

\section{*Corresponding author details: Ryke Ayuningtyas; rykeeayuningtyas@gmail.com}

\begin{abstract}
The higher the organizational commitment of the employees, the better they will provide services to consumers. However, if there are obstacles or shocks during the company's career, of course the organizational commitment of the employees will be shaken, and create a feeling of pressure from within the employee or also known as work stress, and after the emergence of work stress in the employee, the desire to move out of the company is unavoidable. This desire is called turnover intention. This study aims to analyze the relationship between organizational commitment and turnover intentions mediated by job stress. Data collection was carried out through distributing questionnaires to employees of PT. The Prime Image of Kendedes Malang. This research uses explanatory research method with quantitative research type. The data analysis tool used in this study is Partial Least Squares (PLS) and uses SmartPLS software. The sampling technique used purposive sampling technique with the condition that employees who have worked more than 5 years at PT. Kendedes Prime Image. So that the samples that were collected were 88 workers (drivers and internal staffs). The results of this study indicate that organizational commitment has a direct effect on turnover intentions and organizational commitment has an effect on turnover intentions through work stress.
\end{abstract}

Keywords: organizational commitment; turnover intentions; work stress; intervening variable

\section{PRELIMINARY}

The increasing demands of community mobility, transportation facilities that are able to provide movement and movement from one place to another quickly will be needed, either the destination of the trip is near or far. Everyone needs transportation in various activities, such as going to school, working, or traveling in order to do some activities. It will not be balanced if the supporting facilities for people who want to travel are still not adequate, such as public transportation which often feels uncomfortable, overcrowded transport capacity, lack of services in it, and it is not uncommon to find criminal acts on public transportation. So based on these issues, transportation services that are fast, relatively cheap, easy to find, safe, comfortable, and practical are the solutions most needed by today's society (Tumuwe et al., 2018).

The one example of land transportation that has evolved to the current modern era is taxis. Taxis are public transportation vehicles that have lights on the top, accompanied by a characteristic tool for calculating the amount of travel costs called the 'argometer' or the cost of opening the door plus the fare per kilometer. Of course, with the current digital era, an innovation has emerged in the form of a taxi equipped with an online-based application. The change in this era indeed makes conventional transportation unable to survive in the business world and retain its customers, especially after the online motorcycle taxi service, which is booming in the community recently. If the taxi company does not keep up with environmental changes, it will gradually be displaced by other competitors within the same market share.

One of the taxi companies that is well known by the public, especially in the Malang City, is Citra Taxi, which provides services in the form of picking up and delivering passengers comfortably and safely to their destination. Until now, the Citra Perdana Kendedes Taxi company continues to improve its services so that it can keep pace with technological advances and retain customers.

For example, Citra Taxi has transportation services that prioritize digital trends, due to online transportation services in this era, conventional taxi service providers also adopt digital-based technology in order to stay in the midst of market share. This technology adaptation was motivated by the reality on the ground, where not only taxis experienced a shock in the midst of their time, urban transportation or microbuses also experienced a decline which led to the emergence of various demonstrations and anarchism.

Based on the standard of transportation fare regulated in the Regulation of the Mayor of Malang City No. 1 of 2014 concerning Amendments to the Regulation of the Mayor of 
Malang City No. 25 of 2013 concerning taximeter taxi fares, as for the details of the tariffs set by Citra Malang Taxi, it is as follows:

TABLE 1: Citra Taxi Regular Fares

\begin{tabular}{|l|c|}
\hline \multicolumn{1}{|c|}{ INFORMATIONS } & CHARGES \\
\hline Door opening rates (flag fall) & IDR 5.000, - \\
\hline Fares per kilometer & IDR 3.600, - \\
\hline Hourly-waiting rate & IDR 36.000, - \\
\hline
\end{tabular}

However, since the existence of online-based transportation and the emergence of a lot of competition, Citra Malang Taxi has reduced the minimum fare which was initially around IDR 30,000 to IDR 20,000. This happened because more and more consumers are turning to online transportation services because the minimum fare limit imposed is not too expensive compared to conventional taxi fares.

This is exacerbated by the Covid-19 pandemic which has made taxi companies feel an extraordinary storm, even for PT. Citra Perdana Kendedes had to withdraw its branch company in Batu City to become one in Malang City, due to the shrinking use of taxi services in Batu Tourism City after this pandemic. In addition, there were massive layoffs due to the defeat of technology and the presence of a pandemic that took out more than 300 employees (both internal and external), as for the following data:

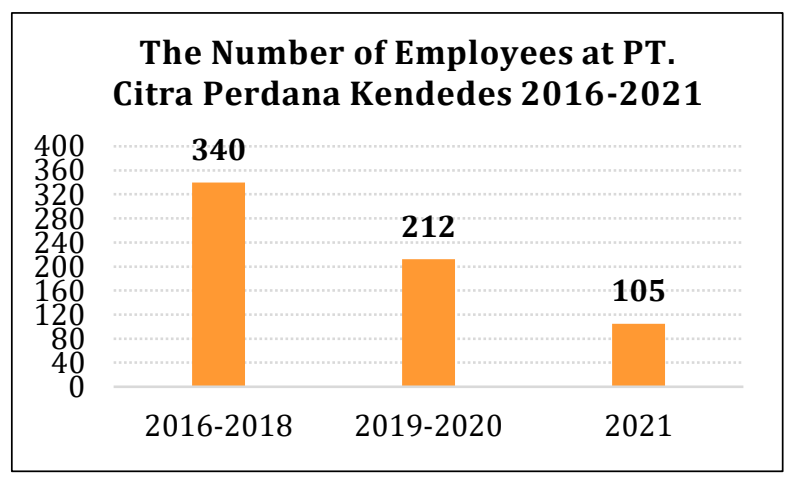

FIGURE 1: Diagram of the Number of Employees in PT. Citra Perdana Kendedes

Based on the data, from 2016 to 2018 there were 341 workers at PT. Citra Perdana Kendedes, and in 2019 to 2020 it was decreased into 212 workers, where the division of the number was 34 internal employees, and 178 drivers. Furthermore, in 2021 there was also a reduction until 105 workers only, where the division of the number is 25 internal employees, and 80 drivers.

From these two big problems, the organizational commitment of the employees of PT. Citra Perdana Kendedes is a topic that needs to be discussed more deeply. Of course, each employee has their own impression and message after the emergence of competitors and the crisis period, and not a few have begun to fade organizational commitment.

\section{LITERATURE REVIEW}

\section{Organizational Commitment}

According to Landy \& Conte (2004), organizational commitment is a belief that reflects the strength of one's attachment to the organization. Where the commitment refers to the emotional and psychological closeness of the individual, and often becomes a sense of pride from the individual towards the goals and relationship to the company. Organizational commitment itself can be interpreted as the desire of workers/employees to maintain their existence and participation in the organization where they work.
Furthermore, according to Allen \& Meyer (1996), organizational commitment is defined as a stage where employees are loyal and psychologically attached to their organization, and tend not to want to leave the organization. In other words, commitment refers to a person's emotional and psychological closeness, so that the individual is proud of his relationships and organizational goals, as well as the perceived condition involving an emotional attachment, and an evaluation of the current state, as well as what is expected in the present and future. which will come. This certainly has an important role in it, given that PT. Citra Perdana Kendedes is a type of service company, where workers will meet directly with consumers, an organizational commitment is certainly needed for comfort and trust in the company from workers which will also be felt by consumers. In another sense, the higher the organizational commitment of the employees of PT. Citra Perdana Kendedes, the better they will provide services to consumers, because of their love and trust in the company. This is in accordance with the results of the initial interview that was carried out with the resource person Mr. Cholil as the Head of the Division. Public Relations at PT. Citra Perdana Kendedes, who said that the average length of working years for internal employees there is $15-30$ years. This indicates, before the occurrence of these problems, employee organizational commitment can be said to be high. However, if there are obstacles as mentioned above, of course, the organizational commitment of the employees will be shaken, and create a desire to change companies, whether to the similar kind of companies or not. This desire is called turnover intention.

\section{Turnover Intentions}

Turnover intention according to Robbins \& Judge (2007), is a time when an employee has a tendency to quit his job, while turnover is a permanent resignation either voluntarily or involuntarily from an organization. Turnover itself can be interpreted as a transfer or movement made by employees to leave the company / organization, as well as high turnover in a company which also causes the operational activities of an organization to be less effective due to the loss, replacement, and inconsistent number of experienced employees employed. work in it. According to Robinson \& Aprilia (2005), turnover intention itself can be suppressed when employees are given better attention, especially on stress levels and their commitment to work.

There are many factors that influence turnover intention, including work stress and organizational commitment (Roslan et al., 2012). This is supported by the statement of Adi \& Ratnasari (2015), which saying that one of the factors that influence the emergence of turnover intention is organizational commitment, where organizational commitment itself can contribute in predicting important variables in the company / organization. According to Sianipar \& Haryanti (2014), the conclusion of the research showed a negative result between turnover intentions and organizational commitment, the results show that the lower the organizational commitment, the higher the turnover intention. The same result was proven by Widyadmono (2015), where the results of the research showed that there is a negative relationship between organizational commitment and turnover intention. However, the results of previous research conducted by Wulansari et al., (2017) saying that organizational commitment had no effect on turnover intention in the object of the research.

\section{Work Stress}

According to Anwar (1993), job stress is a feeling within employees that suppresses, or a sense of pressure experienced 
in dealing with work. Another definition from Coulter (2004), work stress is an excessive workload, so that the employees may have difficult feelings and emotional tension, which can hinder the individual's performance at work. Coulter also stated that work stress can cause deviations in the psychological, physical, and behavioral functions of an employee, and can cause deviations from normal functions.

Smith (1981), stated that the conception of job stress can be viewed through several views; First, job stress can arise as a result of workplace conditions. Second, work stress can arise from two company factors, namely employee involvement in tasks, and the lack of company support. Third, stress can arise because of the "work load". Fourth, work stress can also be caused by excessive working time. Then fifth, the feeling of pressure from the many work responsibilities.

Each employees have a classification of their duties that must be carried out in accordance with company regulations, and which are expected by their superiors. But even so, employees are not always successful or perfect in their way, some of them continue to carry out their roles in the company, but still can cause various kinds of problems. These problems, according to Hidayati et al., (2008) arise because of the lack of optimal role functions that can cause feelings of stress, and are followed by conflicts and role ambiguity.

The research from Biantoro \& Sihombing, (2012), indicated results that Organizational Commitment has no effect on Turnover Intention with Job Satisfaction as intervening variable. In addition, the results of the research by Härtel et al., (2015), indicated that organizational commitment variable has less influence on turnover intention than job satisfaction variable. So, based on the contradictory results and suggestions from previous research, the researcher wants to conduct further research to find out whether Organizational Commitment will affect Turnover Intention through Work Stress as the intervening variable.

\section{RESEARCH METHODS}

This research uses a quantitative approach, with a measuring instrument in the form of a questionnaire which is directly given to the respondents. And the data obtained in the form of answers from the employees of PT. Citra Perdana Kendedes Malang. Based on the research objectives that have been set above, this research is categorized as an explanatory research type, where according to Supriyanto \& Machfudz (2010), explanatory research is to examine hypothesized variables. There are three variables in this research, the independent variable which is Organizational Commitment, the dependent variable namely Turnover Intention, and the intervening variable namely Job Stress.

This research was conducted at PT. Citra Perdana Kendedes Malang City which is located on Jl. Bunga Merak, no. 2, Malang City. The population used in this study is the employees at PT. Citra Perdana Kendedes who have worked for at least 5 years. Based on these criteria, there were 88 workers (interns and drivers) identified.

This study uses the Nonprobability Sampling technique, which according to Supriyanto \& Ekowati (2019), means a sampling technique that does not provide equal opportunities for all members of the population to be sampled. In this study, the method that will be used is purposive sampling method, namely the determination of the sample is carried out with certain considerations, adjusted to the objectives and research problems
(Sugiyono, 2019). Based on the variable of this study, namely Organizational Commitment, the criteria used in this study were the employees who have worked for more than five years at PT. Citra Perdana Kendedes Malang. The data analysis tool used in this study is Partial Least Squares (PLS) and the SmartPLS software.

\section{RESEARCH RESULTS AND DISCUSSION Quantitative Data Analysis}

Based on the data obtained from PT. Citra Perdana Kendedes Malang, the number of questionnaires that have been distributed to the respondents were 105 questionnaires. To determine the sample in this study used purposive sampling method, which is only for workers who have worked more than 5 years. Based on these requirements, the number of workers that qualified the requirements has been filtered, namely 88 workers who have worked for more than 5 years. The results of the sample size and description of respondents are as follows:

TABLE 2: Respondent Description

\begin{tabular}{|c|c|c|c|}
\hline No. & $\begin{array}{l}\text { Respondent } \\
\text { Descriptions }\end{array}$ & Amount & $\begin{array}{c}\text { Prosentase } \\
\text { (\%) }\end{array}$ \\
\hline 1. & $\begin{array}{l}\text { Age } \\
\text { a) } 20-30 \\
\text { b) } 31-40 \\
\text { c) } 41-50 \\
\text { d) }>51\end{array}$ & $\begin{array}{c}8 \\
32 \\
38 \\
10\end{array}$ & $\begin{array}{c}9 \% \\
36 \% \\
44 \% \\
11 \%\end{array}$ \\
\hline \multicolumn{2}{|r|}{ Total } & 88 & $100 \%$ \\
\hline 2. & \begin{tabular}{ll}
\multicolumn{2}{l}{ Gender } \\
a. & Male \\
b. & Female
\end{tabular} & $\begin{array}{c}84 \\
4\end{array}$ & $\begin{array}{c}96 \% \\
4 \%\end{array}$ \\
\hline \multicolumn{2}{|r|}{ Total } & 88 & $100 \%$ \\
\hline 3. & $\begin{array}{ll}\text { Position } \\
\text { a. } & \text { Internal } \\
& \text { Employees } \\
\text { b. } & \text { Drivers }\end{array}$ & $\begin{array}{l}25 \\
63\end{array}$ & $\begin{array}{l}28 \% \\
72 \%\end{array}$ \\
\hline \multicolumn{2}{|r|}{ Total } & 88 & $100 \%$ \\
\hline 4. & $\begin{array}{l}\text { Work Period } \\
\text { a. } \quad 5-10 \text { years } \\
\text { b. } 11-20 \text { years } \\
\text { c. } 21-30 \text { years }\end{array}$ & $\begin{array}{l}30 \\
10 \\
48\end{array}$ & $\begin{array}{l}34 \% \\
11 \% \\
55 \%\end{array}$ \\
\hline \multicolumn{2}{|r|}{ Total } & 88 & $100 \%$ \\
\hline
\end{tabular}

The structural model of this research can be seen in the following figure:

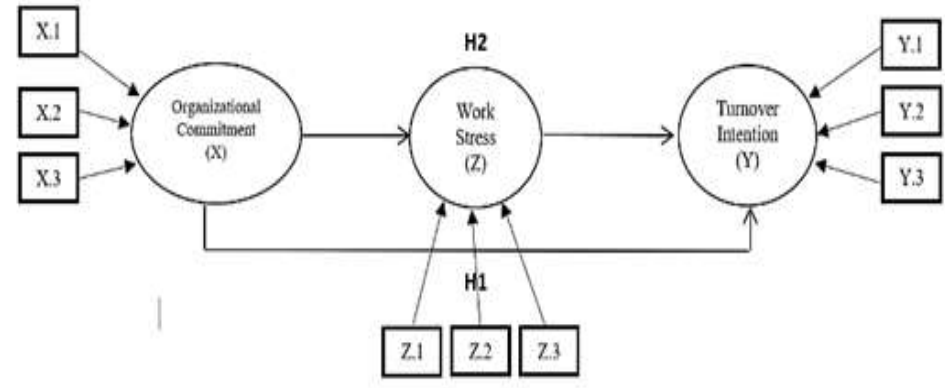

FIGURE 2: Structural Model of Research on the Effect of Organizational Commitment on Turnover Intentions with Work Stress as an Intervening Variable

\section{Results and Discussion}

The computation of the research hypothesis begins with conducting a t-test on the path of each variable with a partial direct effect. The following are the results of the analysis of the direct influence hypothesis testing: 
TABLE 3: Result of Direct Effect Test

\begin{tabular}{|c|c|c|c|c|}
\hline $\begin{array}{c}\text { Independent } \\
\text { Variable }\end{array}$ & $\begin{array}{c}\text { Dependent } \\
\text { Variable }\end{array}$ & $\begin{array}{c}\text { Path } \\
\text { Coef }\end{array}$ & p-value & Result \\
\hline $\begin{array}{c}\text { Organizational } \\
\text { Commitment }\end{array}$ & $\begin{array}{c}\text { Turnover } \\
\text { Intentions }\end{array}$ & -0.681 & 0.000 & Sig \\
\hline $\begin{array}{c}\text { Organizational } \\
\text { Commitment }\end{array}$ & Work Stress & -0.526 & 0.000 & Sig \\
\hline Work Stress & $\begin{array}{c}\text { Turnover } \\
\text { Intentions }\end{array}$ & 0.213 & 0.008 & Sig \\
\hline
\end{tabular}

The results of the direct effects test can also be seen in the path model image as shown in Figure 2.

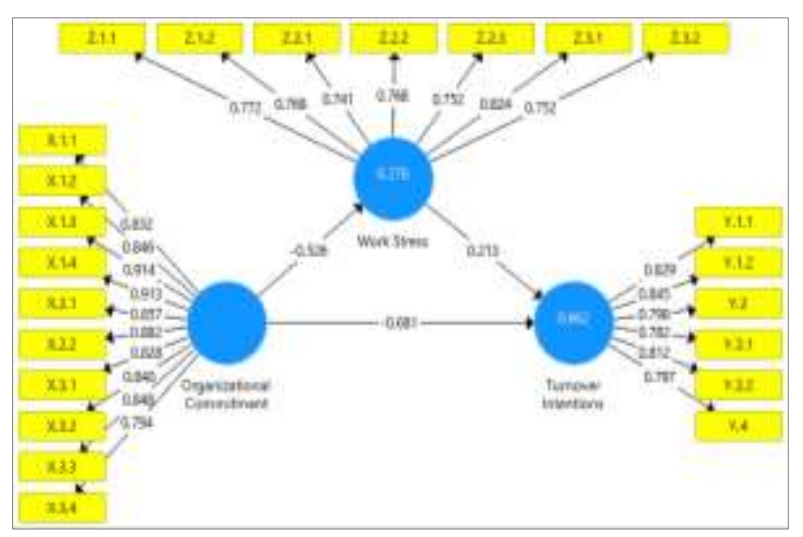

FIGURE 3: PLS Structural Path Diagram Model

The results of hypothesis testing based on Table 3 and Figure 2 above, it can be seen that there are 3 (three) direct effect paths between the variables in this study. The overall test results will be described with the following explanation:

\section{The Effect of Organizational Commitment on Turnover Intentions}

The results about the influence of organizational commitment on turnover intentions obtained a path coefficient value of -0.681 . The results of the $t$-statistic value obtained were $8.644>1.96$. With a p-value of 0.00 . Then the organizational commitment variable can directly affect turnover intentions. It can be concluded that organizational commitment has a negative and significant effect on turnover intentions. The purpose of this result is that the higher the employee's organizational commitment, the lower the desire of turnover intentions towards employees.

The result of this research supports the research conducted by Basri, (2012) which indicated that organizational commitment has a significant negative effect on turnover intentions. This is in line with the results of the research of Saputro et al., (2016) which states that organizational commitment has a negative influence on turnover intentions. The result of this study is organizational commitment has a negative and significant influence on turnover intention. The result of this study also supports the research conducted by Widyadmono (2015) which showed that there is a significant negative relationship between organizational commitment and turnover intentions, and rejects the results of research conducted by Wulansari et al., (2017) which states that there is no effect between organizational commitment and turnover intentions.

According to Landy \& Conte (2004), organizational commitment is a belief that reflects the strength of one's attachment to the organization. Something that exists in employees in the form of belief and loyalty to the company, by being obedient and loving the company. Meanwhile, according to Robbins \& Judge (2007), turnover intentions are the moment when an employee has a tendency to quit his job, while turnover is a permanent resignation either voluntarily or involuntarily from an organization.

Carrying out a commitment with all the consequences of the risks to the pledge that has been made, both inwardly and outwardly, it is fitting for a worker to have high confidence and try seriously so that maximum and halal results will be achieved in accordance with Sharia'. As Allah SWT says in Surah Fushshilat verse 30:

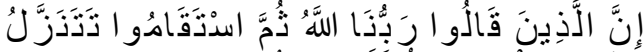

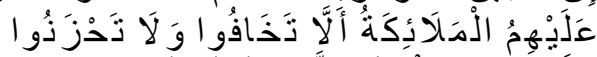

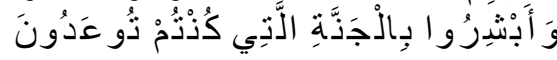

Meaning: "Indeed those who say: "Our Lord is Allah" then they strengthen their position, then the angels will descend to them saying: "Do not be afraid and do not feel sad; and make them happy with Jannah which Allah has promised уои. "

In the paragraph above, it can be concluded that a strong belief and determination from within an employee will encourage the employee to be physically and mentally consistent in carrying out a contract with a company or work organization. The determination or istiqomah of an employee, God willing, will be rewarded by being placed in the best place by God's promise to his creatures, so do not doubt God's promise.

This direct effect of organizational commitment on turnover intentions has a large influence even though it passes through the work stress variable. This means that organizational commitment can effectively have a direct or indirect influence on an employee's desire to change companies which is also called turnover intentions. So that an employee's determination and belief in his work can be influenced by various factors, one of which is work stress. The sense of confidence and determination given by the company by employees is certainly needed for the sustainability of the company in the future, so a strong organizational commitment will be able to reduce the value of turnover intentions for employees of PT. Citra Perdana Kendedes Malang.

\section{The Effect of Organizational Commitment on Turnover} Intentions Through Work Stress

Based on the analysis of the inner model in this study, the effect of organizational commitment variable to turnover intentions (a) has a path coefficient value of -0.681 with a significance of $0.000<0.05$ in a negative direction. On the other hand, the relationship of organizational commitment to work stress (b) has a direct effect on the path coefficient value of -0.526 with a negative direction and a significance of $0.000<0.05$. Likewise, the relationship of work stress variable has a direct effect on turnover intentions with a path coefficient value of 0.213 and a significance of 0.008 $<0.05$ in a positive direction. Also, on the results of the Sobel test there is a T arithmetic value of $30.85>1.95$ and a significance value of $0.000<0.05$ which indicates that work stress has a close relationship between organizational commitment variable and turnover intentions at PT. Citra Perdana Kendedes Malang.

The results of this study are in line with research conducted by Parwati \& Suardana (2015), which showed a negative relationship between organizational commitment to work stress, and a significant negative relationship between organizational commitment and turnover intentions. Research by Caesarani \& Riana (2016), also shows a significant negative relationship between job stress and 
organizational commitment, and a significant positive relationship between job stress and turnover intentions. In addition, research by Nasution (2017) and Paat et al. (2017), showed the same result, namely that there was a significant negative relationship between work stress and organizational commitment and a significant positive relationship between job stress and turnover intentions.

Steers \& Porter (1983:520), defined a form of organizational commitment that arises not only passive loyalty, but also often involves an active relationship with the company, and has the aim of giving maximum effort for the success of the company / work organization concerned. While Mowday (1982:64) defined organizational commitment as a relative strength of an individual in his involvement with the company / work organization. In addition, itu Mitchel (1982:136) defined organizational commitment as a value orientation towards employee performance which shows that the employee really thinks about his work, gets life satisfaction, and gives status to the individual.

The results of respondents' answers regarding to the research at PT. Citra Perdana Kendedes Malang shows the relationship between organizational commitment in employees and a sense of wanting to move or turnover intentions in the company. Likewise, work stress makes employees more likely to want to leave the company.

Wahyuni et al., (2014), stated that work stress is one of the supporting factors for the occurrence of turnover intentions in employees. Work stress is a very important thing and needs to be considered for companies in managing the mental health of their employees for the sustainability of the company in the future, as the word of Allah SWT in QS. Ali 'Imron: 139, namely:

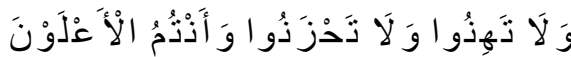

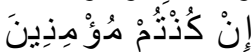

Meaning: "Do not be weak, and do not (also) be sad, even though you are the highest (degrees), if you are believers."

Every human being has trials and lessons that are given by their respective lives. The need to look back, how far we've come, and discouraged from despair. Negative ways of thinking that can increase stressor levels can threaten and harm the employee, and it needs to be changed into positive thinking to stressor levels as something not to worry about. Because, humans are the people of the highest degree if they are the people who believe.

The Results of Inner Path Coefficient Analysis on PLS The results in this study support the results of previous research conducted by Basri (2012), that organizational commitment has a significant negative effect on turnover intentions. This can be interpreted that the higher the employee's organizational commitment, the lower the level of turnover intentions in the employee. The results also in line with the theory put forward by (Roslan et al., 2012) which says there are many factors that influence turnover intention, including work stress and organizational commitment. One of the factors that influence the emergence of turnover intention is organizational commitment.

This is supported by the statement of Adi \& Ratnasari (2015), who said that one of the factors that influence the emergence of turnover intention is organizational commitment.

\section{CONCLUSIONS AND SUGGESTIONS} Conclusions

Increased organizational commitment will affect the decrease in the level of turnover intentions. One of the reasons for the increase in employee turnover intentions is the work stress factor in the employee.

Based on the research that has been done, it can be concluded that 1) Organizational Commitment has a negative and significant effect on Turnover Intentions; 2) Job Stress is able to mediate the effect of Organizational Commitment on Turnover Intentions.

\section{Suggestions}

Based on the results of the analysis and the limitations in this study, it is hoped that in future studies can use different or varied mediating variables to examine the relationship between organizational commitment to turnover intentions and differences in research results that will complement each other.

\section{REFERENCES}

[1] Adi, A. Z., \& Ratnasari, S. L. (2015). Pengaruh Komitmen Organisasi, Penghargaan dan Kepuasan Kerja Terhadap Perputaran Karyawan Pada Perbankan Syariah di Kota BATAM. Etikonomi, 14(1), 35-50.

[2] Allen, N. J., \& Meyer, J. P. (1996). Affective, Continuance, and Normative Commitment to the Organization: An Examination of Construct Validity. 276(49), 252-276.

[3] Anwar, P. (1993). Manajemen Sumber Daya Manusia.

[4] Basri, Y. M. (2012). Hubungan antara keadilan prosedural, job stress, komitmen organisasi dan keinginan berpindah. Jurnal Akuntansi, 1(1), 23-37.

[5] Biantoro, L. C., \& Sihombing, R. P. (2012). Pengaruh Komitmen Organisasi Terhadap Turnover Intention Melalui Kepuasan Kerja Dengan Budaya Organisasi Sebagai Variabel Anteseden. Jurnal Akuntansi Bisnis, 11(21), 61-94.

[6] Caesarani, A., \& Riana, I. (2016). Pengaruh Stres Kerja Terhadap Komitmen Karyawan Dan Turnover Intention Pada Sari Segara Resort Villa \& Spa. EJurnal Manajemen Universitas Udayana, 5(9), 255142.

[7] Coulter, R. (2004). Manajemen (7th ed.). PT. Indeks Group.

[8] Härtel, C. E. J., Zerbe, W. J., \& Ashkanasy, N. M. (2015). New ways of studying emotions in organizations. Research on Emotion in Organizations, 11, xvii-xxiv.

[9] Hidayati, R., Purwanto, Y., \& Yuwono, S. (2008). Kecerdasan Emosi, Stres Kerja Dan Kinerja Karyawan. Jurnal Ilmiah Psikologi Gunadarma, 2(1), 98942.

[10] Landy, F. J., \& Conte, J. M. (2004). Work in the 21st Century: An Introduction to Industrial and Organizational Psychology. McGraw-Hill.

[11] Mitchell. (1982). People in Organization: in Intoduction to Organization Behavior. MC Graw Hill Book Comp.

[12] Mowday. (1982). Employ Organization Linkages: The Psychology of Commitmen Abstein. And Turn Over. Academic.inc. 
[13] Nasution, M. I. (2017). Pengaruh Stres Kerja, Kepuasan Kerja Dan Komitmen Organisasi Terhadap Turnover Intention Medical Representative. MIX: Jurnal Ilmiah Manajemen, 7(3), 224238.

[14] Paat, G., Tewal, B., \& Jan, A. B. H. (2017). Pengaruh Komitmen Organisasi, Kepuasan Kerja, Stres Kerja Terhadap Turnover Intention Karyawan Kantor Pusat Pt. Bank Sulutgo Manado. Jurnal EMBA: Jurnal Riset Ekonomi, Manajemen, Bisnis Dan Akuntansi, 5(3), 3444-3454.

[15] Parwati, N. L. W., \& Suardana, I. B. R. (2015). FaktorFaktor Yang Mempengaruhi Turnover Intention Dengan Variabel Intervening Kepuasan Kerja Dan Komitmen Organisasi. Jurnal Manajemen Dan Bisnis, 14(1), 1-7.

[16] Robbins, \& Judge. (2007). Organizational Behavior Pearson/Prentice Hall.

[17] Robinson, \& Aprilia. (2005). Pengaruh Komitmen Organisasi, Kepuasan Kerja, dan Keperilakuan Etis Terhadap Keinginan Berpindah Pada Profesional Bidang Teknologi Informasi. Bisnis \& Manajemen, $5(1)$.

[18] Roslan, M., Nor, M., Sakat, A. A., Sulaiman, A., \& Naim, A. (2012). The Relationship Between Job Satisfaction and Turnover Intention the Relationship Between Job Satisfaction and Turnover Intention Faculty of Business Management, Department of Al Quran and Al Sunnah Studies, January.

[19] Saputro, H., Fathoni, A., \& Minarsih, M. M. (2016). Pengaruh Kepuasan Kerja, ketidakamanan kerja dan komtimen organisasi terhadap intensi pindah kerja (Turnover Intention) (Studi kasus pada Distribution Center PT. Sumber Alfaria Trijaya Cabang Rembang, Jawa Tengah). Journal of Management, 2(02).

[20] Sianipar, A. R. B., \& Haryanti, K. (2014). KERJA DENGAN INTENSI TURNOVER PADA KARYAWAN. Psikodimensia, 13(1), 98-114.
[21] Smith, M. (1981). Occupational Stress: An Overview of Psychologi Factors. Taylor \& Francis.Ltd.

[22] Steers, \& Porter. (1983). Motivation and Work Behavior. Accademic Press.

[23] Sugiyono. (2019). Metode Penelitian Kuantitatif, Kualitatif, dan R\&D (I). ALFABETA.

[24] Supriyanto, Achmad Sani, \& Ekowati, V. M. (2019). Riset Manajemen SDM. Inteligensia Media.

[25] Supriyanto, Ahmad Sani, \& Machfudz, M. (2010). Metodologi Riset. Manajemen Sumber Daya Manusia. UIN Maliki Press.

[26] Tumuwe, R., Damis, M., \& Mulianti, T. (2018). Pengguna ojek online di kalangan mahasiswa Universitas Sam Ratulangi Manado. Jurnal Holistik, $21,1-19$

[27] Wahyuni, A. S., Zaika, Y., \& Anwar, R. (2014). Analisis Faktor-Faktor yang Mempengaruhi Turnover Intention (Keinginan Berpindah) Karyawan pada Perusahan Jasa Konstruksi. Jurnal Rekayasa Sipil, 8(2), 89-95.

[28] Widyadmono, V. M. (2015). PENGARUH KEPUASAN KERJA DAN KOMITMEN ORGANISASI TERHADAP TURNOVER INTENTION (Studi pada Accounting Staff Perusahaan Swasta di DIY). Manajemen Indonesia, 15.

[29] Wulansari, Y. A., Koesmono, T., \& Junaedi, M. (2017). Pengaruh Keadilan Prosedural dan Stres Kerja terhadap Turnover Intention dengan Komitmen Organisasional sebagai Variabel Mediasi pada PT . PJB Services. 6(2), 112-124. 